\begin{tabular}{|c|c|c|c|}
\hline & $\begin{array}{l}\text { Hæmocyto- } \\
\text { meter } \\
\text { count }\end{array}$ & $\begin{array}{l}\text { Estimated num } \\
\text { Agar disk method }\end{array}$ & $\begin{array}{l}\text { bers } \\
\text { Test-tube } \\
\text { method }\end{array}$ \\
\hline $\begin{array}{l}\text { Experiment } 1 \\
\text { Saline control } \\
\text { Soil }\end{array}$ & $\begin{array}{l}500,000 \\
500,000\end{array}$ & $\begin{array}{c}311,000 \\
5,080 \\
\text { (1 per cent recovery) }\end{array}$ & $\begin{array}{l}650,000 \\
931,000\end{array}$ \\
\hline $\begin{array}{l}\text { Experiment } 2 \\
\text { Saline control } \\
\text { Soil }\end{array}$ & $\begin{array}{l}500,000 \\
500,000\end{array}$ & $\begin{array}{c}380,000 \\
41,400 \\
\text { (8 per cent recovery) }\end{array}$ & $\begin{array}{l}931,000 \\
520,000\end{array}$ \\
\hline
\end{tabular}

All figures represent number of organisms/gm, soil or ml. saline

from the disk and tube dilutions obtained in two experiments are given in Table 1 .

Both disk and tube methods gave a satisfactory 'recovery' of numbers from the suspensions in saline, having regard to the limited accuracy of a dilution method. The test-tube method also gave satisfactory recovery from the soil suspension; but with disks, recovery was only 1 per cent and 8 per cent in the two experiments.

A recovery test was then made in unsterilized soil to see whether sterilization of the soil had produced substances harmful to growth. A counted suspension of Nitrosomonas was added to fresh soil. Numbers were then estimated by the disk method from this soil and from an uninoculated control soil. In a later experiment, a similar test was made with the tube method. The results (Table 2) again show that the fresh soil has interfered with the recovery of added numbers in the disk method, but not with the tube method.

Table 2. RECOVERY OF Nitrosomonas FROM UNSTERILIZED SOII

\begin{tabular}{|c|c|c|}
\hline & $\begin{array}{c}\text { No. of organisms } \\
\text { added, per gm. soil }\end{array}$ & $\begin{array}{c}\text { No. of organisms estim- } \\
\text { ated, per gm. soil }\end{array}$ \\
\hline $\begin{array}{c}\text { Agar disk technique } \\
\text { Uninoculated soil } \\
\text { Inoculated soil }\end{array}$ & 600,000 & 6,040 \\
$\begin{array}{c}\text { Test-tube technique } \\
\text { Uninoculated soil } \\
\text { Inoculated soil }\end{array}$ & 500,000 & 22,400 \\
& 0 & 5.75 per cent recovery $)$ \\
\hline
\end{tabular}

These results point to some factor introduced by the soil which interferes with growth on agar disks, but not in test-tubes, where it is perhaps diluted out. The nature of this factor will be further investigated.

Soil Microbiology Department, J. W. MIILBaNK*

Rothamsted Experimental Station, Harpenden, Herts.

* Present address : East African Agriculture and Forestry Research Organization, P.O. Box 21, Kikuyu, Kenya.

${ }^{I}$ Stevenson, I. L., and Chase, F. E., Soil Science, 76, 107 (1953).

2 Singh, B. N., Ann. App. Biol., 33, 112 (1946).

"Fisher, R. A., and Yates, F., "Statistical Tables for Biological, Agricultural and Medical Research", 2nd edit., Table VIII (Oliver and Boyd, London, 1943).

\section{Nucleus and Spindle of Bacillus megaterium in Fission and Sporulation}

IN a recent communication in Nature, Yuasa ${ }^{1}$ contends that the 'side-body' of the spores of Bacillus megaterium is identical with the spindle of the dividing yeast nucleus, and acts as such in a mitotic division of the bacterial nucleus.

This is quite unacceptable for the following reasons : (1) The theory of a mitotic division in $B$. megaterium, advanced by DeLamater ${ }^{2}$, so far from being regarded even as a problematical alternative to the now classical concept of the bacterial nucleus ${ }^{3}$, has been very severely criticized on both theoretical and practical grounds by leading authorities in all parts of the world4. (2) The 'side-body' has now been proved conclusively to be an artefact caused by partial ejection of the turgid nuclear contents of the spore ${ }^{5}$. (3) The 'large-body' in the vegetative bacillus, which Yuasa claims to be identical with the 'side-body', appears from his diagrams to represent the polar aggregate of basophilic material associated with the growing tip of the celle.

The apparent contention of Yuasa that the authors whom he quotes themselves equate this structure in the sporing bacillus with the 'side-body' (that is, the ejected nucleus) of the spore is without foundation.

Department of Bacteriology,

M. H. Jeynes

University of Birmingham, Birmingham 15.

1 Yuasa, A., Nature, 177, 386 (1956).

DeLamater, E. D., and Hunter, M. E., Amer. J. Bot., 38, 659 (1951). DeLamater, E. D., and Mudd, S., Exp. Cell Res., 2, 499 (1951)

${ }^{3}$ Robinow, C. F., in Dubos, R. J., "The Bacterial Cell" (Harvard, 1945). Bisset, K. A. "The Cytology and Life History of Bacteria", 1945). Bisset, K. A., "The Cytology and Life

4 Tulasne, R., and Vendrely, C., Schweiz. Z. Path. Bakt., 17, 649 (1954). Clark, J. B., and Webb, R. B., J. Gen. Microbiol., 11, 394 (1954) Bisset, K. A., J. Baet., 67, 41 (1954). Hale, C. M. F., Exp. Cell Res., 6, 243 (1954).

${ }^{5}$ Bisset, K. A., and Hale, C. M. F., J. Hyg., 49, 201 (1951). Robinow, C. F., J. Bact., 66, 300 (1953); Sixth Symp. Soc. Gen. Microbiol., 181 (1956).

- Bisset, K. A., J. Gen. Microbiol., 5, 155 (1951). Bergersen, F. J., J. Gen. Microbiol, 9,353 (1953).

\section{Use of Capacity Measurements for the Study of Oxide Films on Metals}

EsTrMates of the thickness of oxide films on metals have long been made by immersion in an electrolyte and measurement of the capacity of the condenser formed by the film as dielectric ${ }^{1}$. It has, however, been pointed out by R. Huddle (private communica. tion) that such measurements are liable to error if the film contains cracks, for these permit the electrolyte to approach closer to the metal/oxide interface. This should cause the 'capacity' thickness to be less than that derived from measurements of gain of weight, for example. A rise in the capacity of anodized films under condition of breakdown has been reported by Young ${ }^{1}$.

This behaviour has been turned to advantage in the examination of the films formed in the corrosion of zirconium alloys. When the latter are exposed to water at about $300^{\circ} \mathrm{C}$., the rate of corrosion, as measured by the gain of weight, at first falls with time. At a certain stage, called 'breakaway', the film on most alloys becomes less protective, and the rate changes to a constant, higher, value. All the specimens examined in these experiments had suffered breakaway, except those of the alloy 'Zirealoy 2' (1.5 per cent tin, 0.13 per cent iron, 0.05 per cent nickel, $0 \cdot 12$ per cent chromium, balance zirconium), which is very resistant to corrosion.

Specimens of the alloys detailed in Table 1 were pickled in a solution containing 45 c.c. nitric acid (concentrated), 5 c.c. hydrofluoric acid (48 per cent solution), 50 c.c. water and then weighed. After exposure to water at $325^{\circ} \mathrm{C}$. for periods up to about $500 \mathrm{hr}$. they were reweighed, wires were attached to them, and they were waxed, leaving $l \mathrm{~cm} .{ }^{2}$ (apparent 